\title{
An in vitro study of an Artocarpus heterophyllus substance as a hepatitis $C$ antiviral and its combination with current anti-HCV drugs
}

Adita Ayu Permanasari ${ }^{1}$, Chie Aoki-Utsubo ${ }^{2}$, Tutik Sri Wahyuni ${ }^{1,3}$, Lidya Tumewu ${ }^{1}$, Myrna Adianti ${ }^{1,4}$, Aty Widyawaruyanti ${ }^{1,3}$, Hak Hotta $^{5}$ and Achmad Fuad Hafid ${ }^{1,3^{*}}$

\begin{abstract}
Background: Current therapy of chronic hepatitis C virus (HCV) with direct-acting antivirals (DAAs) has dramatically improved the sustained virologic response (SVR) of affected patients; however, treatment with DAAs remains expensive, and drug-resistant HCV variants remain a threat. As a result, there is still a need to continue to develop affordable and effective drugs for the treatment of HCV. Previously, we have demonstrated that a crude extract from Artocarpus heterophyllus leaves is a potential anti-HCV candidate. In this study, we have further purified this crude extract, examined which sub-fraction possesses the highest antiviral activity, and then explored its efficacy at different HCV life cycle stages. We also assessed synergistic antiviral effects between the A. heterophyllus extract and commercially available anti-HCV drugs.
\end{abstract}

Methods: We used vacuum liquid chromatography (VLC) and high-performance liquid chromatography (HPLC) to fractionate a dichloromethane extract of $A$. heterophyllus leaves. We then examined the anti-HCV activity of the fractions using HCV genotype 2a, JFH1a; the antiviral mode of action was determined by exploring adding the treatments at different times. We examined the antiviral effects on the viral entry stage through a virucidal activity test, viral adsorption examination, and pretreatment of cells with the drug. The effects on the post-viral entry stage were determined by the levels of HCV protein expression and HCV RNA expression in infected cells.

Results: Through activity guided purification, we identified the sub-fraction FR3T3 as possessing the most robust anti-HCV activity with an $I C_{50}$ value of $4.7 \pm 1.0 \mathrm{\mu g} / \mathrm{mL}$. Mode-of-action analysis revealed that FR3T3 inhibited postviral entry stages such as HCV NS3 protein expression and HCV RNA replication with marginal effects on the viral entry stage. Thin-layer Chromatography (TLC) indicated that FR3T3 contained terpenoids and chlorophyll-related compounds. We also found a synergistic antiviral activity when the DCM extract of $A$. heterohyllus was used in combination therapy with commercial anti-HCV drugs; Ribavirin, Simeprevir, Cyclosporin A.

\footnotetext{
* Correspondence: achmadfuad@yahoo.com

'Institute of Tropical Disease, Universitas Airlangga, Surabaya 60115,

Indonesia

${ }^{3}$ Department of Pharmaceutical Sciences, Faculty of Pharmacy, Universitas

Airlangga, Surabaya 60115, Indonesia

Full list of author information is available at the end of the article
}

\section{$\triangle B M C$}

C C The Author(s). 2021 Open Access This article is licensed under a Creative Commons Attribution 4.0 International License, which permits use, sharing, adaptation, distribution and reproduction in any medium or format, as long as you give appropriate credit to the original author(s) and the source, provide a link to the Creative Commons licence, and indicate if changes were made. The images or other third party material in this article are included in the article's Creative Commons licence, unless indicated otherwise in a credit line to the material. If material is not included in the article's Creative Commons licence and your intended use is not permitted by statutory regulation or exceeds the permitted use, you will need to obtain permission directly from the copyright holder. To view a copy of this licence, visit http://creativecommons.org/licenses/by/4.0/ The Creative Commons Public Domain Dedication waiver (http://creativecommons.org/publicdomain/zero/1.0/) applies to the data made available in this article, unless otherwise stated in a credit line to the data. 
Conclusions: The extract of A. heterophyllus and its sub-fraction, FR3T3, presented here have anti-HCV activities and could be candidate drugs for add-on-therapy for treatment of chronic HCV infections.

Keywords: Hepatitis, Artocarpus heterophyllus, Medicine, Infectious Disease

\section{Background}

The hepatitis $\mathrm{C}$ virus $(\mathrm{HCV})$ is a positive-sense singlestranded RNA virus of the Flaviviridae family. The HCV genome is $9.6 \mathrm{~kb}$ in length and encodes three structural proteins (Core, E1, and E2) and seven non-structural proteins (p7, NS2, NS3, NS4A, NS4B, NS5A, NS5B). The structural proteins $\mathrm{El}$ and E2 are responsible for binding the virus to the receptor(s) on the host cell's surface [1]. The non-structural proteins play an essential role in RNA replication, virus assembly, and virus release [2]. The HCV life cycle is mainly divided into seven steps: (1) virus attachment, (2) entry, (3) uncoating, (4) translation, (5) RNA genome replication, (6) assembly and maturation, and (7) virion release [3, 4].

HCV infection is a significant global health burden; it is estimated that 71 million people globally have a chronic HCV infection [5]. HCV causes both acute and chronic hepatitis. Patients with a chronic HCV infection are at a high risk of developing cirrhosis and hepatocellular carcinoma (HCC). Approximately 400 thousand people die every year due to $\mathrm{HCV}$-related complications [6]. HCV strains are classified into seven genotypes (1 to 7) which are distributed worldwide [7]. Direct-acting antivirals (DAAs) are an effective therapy for $\mathrm{HCV}$ that target viral proteins such as NS3/NS4A protease, the NS5A protein, and NS5B polymerase, which are involved in viral replication. There are two generations of NS3/ 4A protease inhibitors: Boceprevir and Telaprevir are considered 1st generation treatments and Faldaprevir, Asunaprevir, Vaniprevir, Paritaprevir, Grazoprevir, Sovaprevir, and Simeprevir are considered 2nd generation. There are also two generations of NS5A protein inhibitors: Daclastavir, Ledipasvir, and Ombitasvir are considered 1st generation and Elbasvir, Velpatasvir, Odalasvir, are considered 2nd generation. There are two groups of NS5B polymerase inhibitors, another class of DAAs: $\mathrm{Nu}-$ cleoside Polymerase Inhibitor's (NPIs) such as Sofosbuvir, and Non-NPIs (NNPIs) such as Dasabuvir [8].

Oral DAA treatment achieves a very high ( $>90 \%)$ sustained virological response (SVR) rate in patients with all genotypes of $\mathrm{HCV}$. However, their expense prevents them from being widely used, particularly in low-income countries. As a result, access is limited to HCV treatment for many in need of it. Furthermore, the emergence of HCV strains that are resistant to DAAs is increasing in prevalence [9-12]. Therefore, there is still a requirement to develop safe and cost-effective alternative anti-HCV agents.
Natural products derived from plants have been used as healing agents for thousands of years. Plants produce a wide variety of secondary metabolites such as flavonoids, terpenoids, lignans, sulphides, polyphenolics, coumarins, saponins, furyl compounds, alkaloids, polyines, thiophenes, proteins, and peptides. Many of these plant chemicals have been reported to possess numerous bioactivities, including antiviral activity. Therefore, medicinal plants are an attractive source for screening antiviral drugs and may lead to the development of new anti-HCV agents $[13,14]$.

Artocarpus spp. are widely cultivated in tropical countries, including Indonesia, and have been used to treat a range of conditions such as skin diseases, diarrhea, and inflammation $[15,16]$. Artocarpus heterophyllus has previously been reported to be effective against Herpes Simplex Virus (HSV), Human Immunodeficiency Virus (HIV), and Varicella-Zoster Virus (VZV) [17-20]. In our previous research, we found that $A$. heterophyllus leaves exhibit anti-HCV activity. In particular, a dichloromethane extract showed the most potent anti-HCV activity with an $\mathrm{IC}_{50}$ value of $1.5 \mu \mathrm{g} / \mathrm{mL}$ [21]. In this study, we fractionate this dichloromethane extract from A. heterophyllus leaves and analyze its anti-HCV activity mechanism of action. Finally, we determine the effectiveness of the dichloromethane (DCM) extract of A. heterophyllus with various current $\mathrm{HCV}$ drugs as a treatment for $\mathrm{HCV}$ infections.

\section{Methods}

\section{General materials}

Silica gel $60 \mathrm{GF}_{254}$ (Merck) was used for vacuum liquid chromatography. Thin-layer Chromatography (TLC) was carried out using silica gel $60 \mathrm{~F}_{254}$ and $\mathrm{RP}-18 \mathrm{~F}_{254}$ plates (Merck). High-performance liquid chromatography (HPLC) was conducted using a Shimadzu system equipped with a LC-6 AD pump and a Diode Array Detector (SPD-M20A), as well as a Zorbax Eclipse XDBC18 column $(9.4 \times 250 \mathrm{~mm}, 5 \mu \mathrm{m}$ particle size, Agilent); mobile phase acetonitrile - water $(9: 1 \mathrm{v} / \mathrm{v})$; flowrate 1 $\mathrm{mL} / \mathrm{min}$, injection volume $500 \mu \mathrm{L}$, wavelength $254 \mathrm{~nm}$ and $365 \mathrm{~nm}$. HPLC solvents were purchased from Merck.

\section{Crude extract preparation, extraction, and fractionation}

The leaves of Artocarpus heterophyllus Lam. were obtained from Purwodadi Botanical Garden, Indonesian Institute of Sciences, East Java, Indonesia and received 
approval for sampling according to regulations Peraturan LIPI nomor 26 tahun 2019. The species was verified by Mr. Matrani as an expert botanist of Purwodadi Botanical Garden, Indonesian Institute of Science, East Java, Indonesia. The voucher speciment has been deposited in material room at Institute of Tropical Disease, Universitas Airlangga by code AH01.

The Artocarpus leaves were extracted using $n$-hexane, which yielded a crude $\mathrm{n}$-hexane extract $(10.8 \mathrm{~g})$. Meanwhile, the residue from $n$-hexane extract was further processed using dichloromethane (DCM) to generate $32.8 \mathrm{~g}$ of DCM extract. The DCM extract was further purified by using bioactivity guided fractionation. The DCM extract was applied to a silica gel vacuum column and eluted in a $25 \%$ gradient of $n$-hexane-dichloromethane $(100: 0$ to $0: 100)$ and a $15 \%$ gradient of dichloromethane-MeOH (100:0 to 90:10). This approach yielded four fractions (FR1 FR4) which were identified based on their TLC profiles. Fraction FR3 (2.4 g) was further partitioned using HPLC (RP-18) and an elution gradient of $\mathrm{ACN}-\mathrm{H}_{2} \mathrm{O}$ (9:1) which yielded a further seven sub-fractions (FR3T1 FR3T7). All extracts, fractions, and sub-fractions were dissolved in dimethyl sulfoxide (DMSO) at a concentration of $100 \mathrm{mg} / \mathrm{mL}$ and then stored at $-30^{\circ} \mathrm{C}$ before used for anti-HCV assay.

\section{Cells and viruses}

A clone from a human hepatoma derived cell line, Huh7it-1 cells [22, 23], were cultured in Dulbecco's Modified Eagle Medium (GIBCO Invitrogen, Carlsbad, CS, USA) supplemented with $10 \%$ Fetal Bovine Serum (Biowest, Nualle, France), $0.15 \mathrm{mg} / \mathrm{mL}$ Kanamycin (Sigma-Aldrich, St. Louis, MO, USA), and non-essential amino acids (GIBCO-Invitrogen) in $5 \% \mathrm{CO}_{2}$ at $37^{\circ} \mathrm{C}$. A cell culture-adapted $\mathrm{HCV}$ variant was propagated as described previously [21, 22, 24]. In brief, a virus culture was created by collecting the supernatant from a Huh7it-1 cell culture infected by HCV JFH1. The supernatant was collected on the third to fifth day after infection and then concentrated using an Amicon filter and stored at $-80^{\circ} \mathrm{C}$.

\section{Virus titration and immunostaining}

Virus titration and immunostaining were performed as described previously [21, 22, 24]. HCV JFH1 was cultivated in Huh7it-1 cells, which were then visualized through immunostaining. The culture supernatant from anti-HCV assay was dilluted 20-fold with medium then inoculated onto cell. Four hours after virus absorption, the remaining virus was removed, and cells were incubated with a medium containing $0.4 \%$ methylcellulose (Sigma-Aldrich) for $40 \mathrm{~h}$. The immunostaining was performed to determine focus formation assay through the infectious foci. Firstly, Cells were fixed using 10\% formaldehyde ( $200 \mu \mathrm{l}$ per well) then washed $3 \mathrm{x}$ with PBS $200 \mu \mathrm{l} /$ well. To permeable cell membrane, triton X 0.5\% $(100 \mu \mathrm{l}$ per well) was added and the cells were incubated for $10 \mathrm{~min}$. $\mathrm{HCV}$ infected patient serum was used to stain HCV antigen-positive cells by combining them at a 1:200 ratio with a solution of BlockAce (2\%), BSA (1\%), PBS and incubated for $1 \mathrm{~h}$. We continued by adding a HRP-goat anti-human Ig antibody (MBL, tokyo, Japan) at a ratio of 1:400 under the same conditions. The enzymatis reaction was identified through reacting HRP and metal enhanced DAB substrate (ThermoFisher ScientificInc., Rockford, IL,USA) which resulted brown color for infected cells. The infectious foci were counted under an inverted microscope.

\section{Antiviral activity assay}

Antiviral activity tests were performed as described previously $[21,22,24]$. In brief, Huh7it-1 cells $\left(5.4 \times 10^{4}\right)$ were challenged with $\mathrm{HCV}$ at a multiplication of infection (MOI) of 0.1 in the presence of different concentrations of fractions or sub-fractions. Two hours after virus adsorption, the cells were rinsed with the medium and were further incubated in the medium for $46 \mathrm{~h}$ at $37^{\circ} \mathrm{C}$ incubator.

\section{Time addition experiment}

To determine the inhibition mechanism of the most active sub-fraction against $\mathrm{HCV}$, a time addition experiment was carried out. Entry stage inhibition was tested using HCV JFH1 (MOI 0.1) and medium containing sample cells for $2 \mathrm{~h}$ and then incubated for $46 \mathrm{~h}$ with added medium without sample. Post entry step inhibition was tested by inoculating cells with $\mathrm{HCV}$, incubating for $2 \mathrm{~h}$, and then adding the sub-fraction and incubating for a further $46 \mathrm{~h}$. Both stage inhibition was performed by added medium containing sample at $2 \mathrm{~h}$ and $46 \mathrm{~h}$ incubation. After $48 \mathrm{~h}$ post-infection (PI) culture supernatants were collected for virus titration. The $50 \%$ inhibitory effect (IC50) was calculated by using the SPSS probit analysis.

\section{MTT assay}

The cytotoxicity of the samples to the cells was assessed using a 3-(4,5-Dimethylthiazol-2-Yl)-2,5-Diphenyltetrazolium Bromide (MTT) assay as described previously [21, 25]. Huh7it-1 cells $\left(2.4 \times 10^{4}\right)$ placed in a 96 well plate were combined with sample at various concentrations and incubated for $48 \mathrm{~h}$. After incubation, the medium was discarded and $150 \mu \mathrm{L}$ of medium containing MTT $(15 \mu \mathrm{L})$ was added and incubated for a further $4 \mathrm{~h}$. Then $100 \mu \mathrm{L}$ of DMSO was added to dissolve the precipitate that formed from the MTT reaction. The absorbance was measured at $560 \mathrm{~nm}$ and $750 \mathrm{~nm}$ wavelengths using the GloMax Microplate Multidetection 
Reader (Promega). Measurement results compared with a control. The resulting $\mathrm{CC}_{50}$ value was analyzed using SPSS analysis.

\section{Virucidal activity assay}

A virucidal activity test was performed as described previously $[21,23]$. In brief, a HCV JFH1 $1 \times 10^{6} \mathrm{FFU} / \mathrm{mL}$ as much as $75 \mathrm{~mL}$ was mixed with the sample and incubated for $2 \mathrm{~h}$ at $37^{\circ} \mathrm{C}$. Cells were then inoculated with 1250 dilutions and incubated for a further $4 \mathrm{~h}$. After that the virus inoculum was removed, MC-DMEM medium was added to the cells and incubated for a further $40 \mathrm{~h}$. Visualization of infected cell colonies was carried out by staining using DAB.

\section{Effect of host expression assay}

Huh7it-1 cells $\left(5.4 \times 10^{4}\right)$ were pretreated with a subfraction from $A$. heterophyllus for $2 \mathrm{~h}$ at $37^{\circ} \mathrm{C}$. The cells were then challenged with HCV (MOI of 0.1 ) for $2 \mathrm{~h}$. The culture supernatant at 46 hpi was collected for virus titration.

\section{Immunoblotting}

$\mathrm{HCV}$ infected cells were lysed in a RIPA buffer, and the protein concentrations were determined using a BCA assay kit (Thermo Fisher Scientific). Equal amounts of proteins were separated using SDS polyacrylamide gel electrophoresis and transferred onto a polyvinylidene difluoride (PVDF) membrane (Millipore, Bed-ford, MA, USA). The membranes were first probed with primary antibodies: a HCV NS3 mouse monoclonal antibody (clone H23; Abcam, Cambridge, MA, USA) and a $\beta$ actin antibody (MBL, Nagoya, Japan) followed by a secondary antibody, HRP-conjugated goat anti-mouse immunoglobulin (MBL) [21, 25]. Target proteins were visualized using an enhanced chemiluminescence detection system (Biorad; GE Healthcare, UK).

\section{Quantitative reverse transcription-polymerase chain reaction (qRT-PCR)}

Extraction of total Ribonucleic Acid (RNA), cDNA preparation, and gene expression quantification by qPCR was performed as described previously [21, 26, 27]. Briefly, RNA was extracted from cells using Trizol. One microgram of total RNA was reverse transcribed using a Reverse Transcription System (Toyobo) using random primers. Real-time quantitative PCR analysis was performed using SYBR Premix Ex Taq (TaKaRa, Kyoto, Japan) on a MicroAmp 96 well plate. The primers used to amplify the region were NS3 $5^{\prime}$-CTTTGACTCC GTGATCGACT-3' (sense) and 5'-CCCTGTCTTCCT CTACCTG-3' (antisense).

\section{Combination treatment experiments}

The $\mathrm{IC}_{50}$ values of commercial antiviral drugs: Telaprevir (Tl) (Adooq Bioscience, Irvine, CA); Simaprevir (Sm) (Toronto Research Chemical, Canada); Ribavirin (Rb) (Sigma Aldrich, MO), and Cyclosporin A (Cy) (WAKO pure chemical, Japan) were determined using SPSS. Combination treatment experiments were conducted at $4 \mathrm{x}, 2 \mathrm{x}, 1 \mathrm{x}, 0.5 \mathrm{x}$, and $0.25 \mathrm{x}$ of $\mathrm{IC}_{50}$ for each drug. Huh7it1 cells were challenged with HCV in the presence of a mixture of $A$. heterophyllus extract and commercial drugs at the indicated concentrations. Compusyn software was used to determine the combination index value (CI). These were defined as: synergism effect: $\mathrm{CI}<1$, addictive effect: $C I=1$, and antagonism effect: $\mathrm{CI}>1$ [22, 28].

\section{Results}

Fractionation of the $A$. heterophyllus dichloromethane extract

Four fractions (FR1-FR4) were obtained from the dichloromethane extract of $A$. heterophyllus using Vacuum Liquid Chromatography (VLC). Bioassay results demonstrated that FR3 and FR4 exhibited strong anti$\mathrm{HCV}$ activities and therefore was subjected to further separation by preparative HPLC. This approach resulted in the isolation of seven sub-fractions (FR3T1-FR3T7) (Fig. 1).

In total, four fractions and seven sub-fractions were isolated from the $A$. heterophyllus dichloromethane extract. FR3T6 was the most abundant sub-fraction (11.9 mg; Table 1), and FR3T2 was the least abundant subfraction (0.3 mg; Table 1$)$.

\section{The anti-HCV activity of $A$. heterohpyllus sub-fractions}

We found five sub-fractions (FR3T1, FR3T2, FR3T3, FR3T5 and FR3T7) possessed strong anti-HCV activities $\left(\mathrm{IC}_{50}\right.$ values of $\left.<10 \mu \mathrm{g} / \mathrm{mL}\right)$. Sub-fraction FR3T4 and FR3T6 did not show any antiviral activity at the tested concentration. Cytotoxicity results showed that FR3T3 was the least toxic in Huh7it-1 cells $\left(\mathrm{CC}_{50}>100 \mu \mathrm{g} / \mathrm{mL}\right)$ among five active subfractions. Sub-fractions FR3T1, FR3T5, and FR3T7 exhibited strong cytotoxic effects on Huh7it-1 cells $\left(\mathrm{CC}_{50}<60 \mu \mathrm{g} / \mathrm{mL}\right.$ ) (Table 2). Based on these results, we focused on sub-fraction FR3T3 in further experiments. This was principally to elucidate the mechanism behind the anti-HCV effects demonstrated by this sub-fraction.

Firstly, we examined the effect of FR3T3 on the viral entry and post-entry stage by conducting time-ofaddition experiments. Huh7it-1 cells were infected with $\mathrm{HCV}$ in the presence or absence of FR3T3 at different points in time. The entry-stage inhibition was determined by FR3T3 addition before viral infection; while the post-entry stage inhibition was determined by 


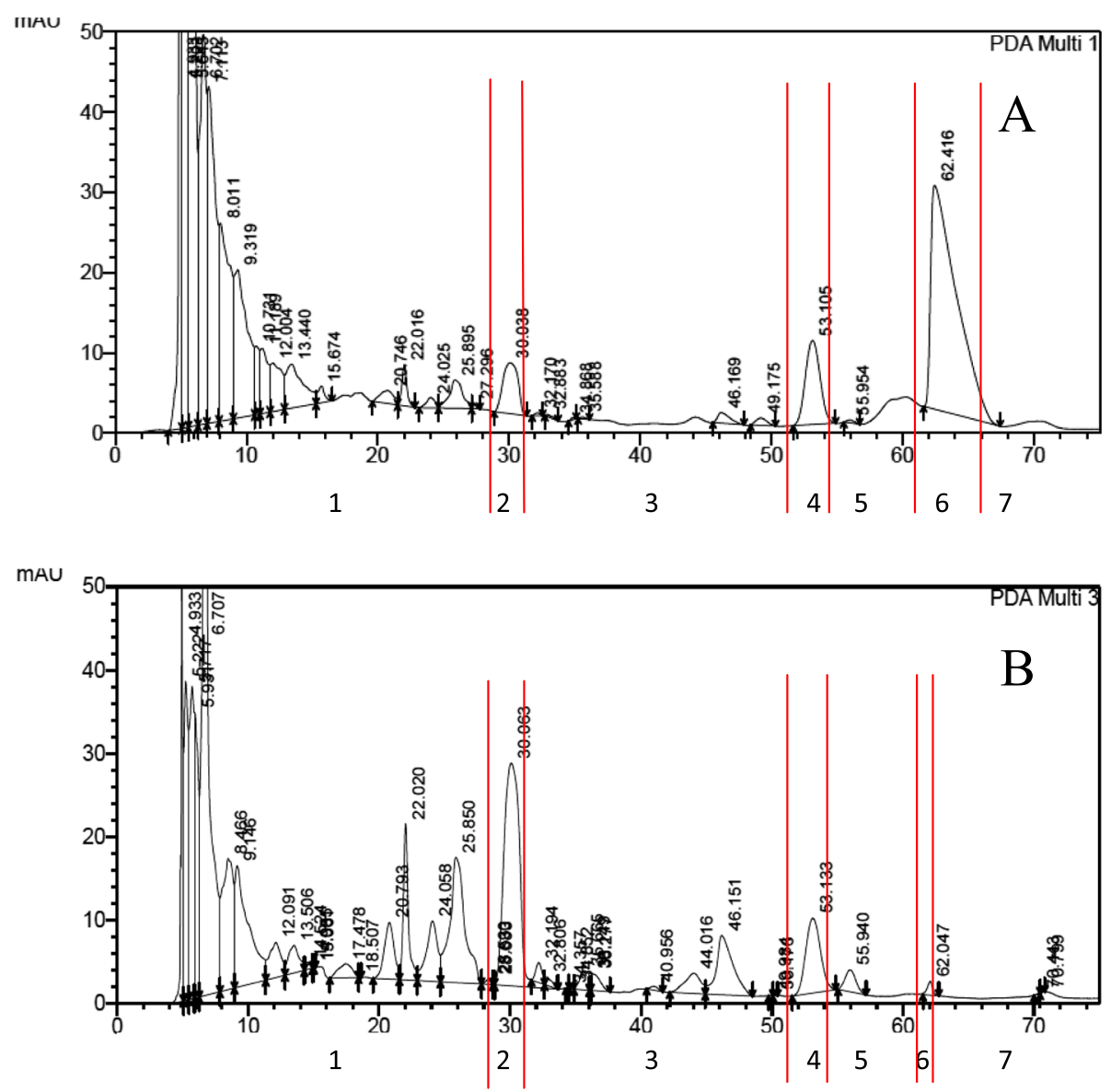

Fig. 1 The FR3 sub-fractionation chromatogram using High Performance Liquid Chromatography (HPLC) at $\lambda 254 \mathrm{~nm}$ and $365 \mathrm{~nm}$. 1). Sub-fraction 1 (FR3T1), 2). Sub-fraction 2 (FR3T2), 3). Sub-fraction 3 (FR3T3), 4). Sub-fraction 4 (FR3T4), 5). Sub-fraction 5 (FR3T5), 6). Sub-fraction 6 (FR3T6), 7). Sub-fraction 7 (FR3T7)

Table 1 Weight and yield of fractions and sub-fractions of $A$. heterophyllus dichloromethane extract

\begin{tabular}{lllll}
\hline Sample & Sample name & Sample code & Weight $(\mathbf{m g})$ & Yield (\%) \\
\hline Extract & DCM Extract & - & 4000.0 & - \\
Fraction & Fraction 1 & FR1 & 49.0 & 1.225 \\
& Fraction 2 & FR2 & 577.0 & 14.425 \\
& Fraction 3 & FR3 & 2591.0 & 64.775 \\
& Fraction 4 & FR4 & 70.0 & 1.75 \\
Sub-fraction & Fraction 3 T1 & FR3T1 & 20 & 10 \\
& Fraction 3 T2 & FR3T2 & 0.3 & 0.15 \\
& Fraction 3 T3 & FR3T3 & 8.5 & 4.25 \\
& Fraction 3 T4 & FR3T4 & 1.3 & 0.65 \\
& Fraction 3 T5 & FR3T5 & 2.2 & 1.1 \\
& Fraction 3 T6 & FR3T6 & 11.9 & 5.95 \\
& Fraction 3 T7 & FR3T7 & 3.8 & 1.9 \\
\hline
\end{tabular}

FR3T3 addition after viral infection. We also investigated the antiviral impact on both stages, simultaneously adding FR3T3 both before and after virus infection. We found that a $10 \mu \mathrm{g} / \mathrm{mL}$ treatment of FR3T3 at the entry or postentry stages inhibited HCV by 33.9 and 64\%, respectively. While the treatment at both stages inhibited HCV by $83 \%$ (Table 3). Furthermore, increasing the treatment dose of FR3T3 to $20 \mu \mathrm{g} / \mathrm{mL}$, increased the suppression of $\mathrm{HCV}$ activity to $61.7 \%$ at the viral entry stage, $83.9 \%$ at the postentry stage, and $93.4 \%$ when the treatment was applied at both stages simultaneously (Table 3 ).

Next, we performed three experiments to determine the mode of action at the entry stage. Firstly, through a virucidal activity test we examined how pretreatment of cells with FR3T3 influenced HCV infectivity and HCV adsorption. We found that FR3T3 at a dose of $20 \mu \mathrm{g} / \mathrm{mL}$ reduces $\mathrm{HCV}$ virion infectivity by $10.1 \%$, compared to an untreated control (Fig. 2A). Pretreatment of cells with FR3T3 inhibited HCV infection by $14.9 \%$ compared to the untreated control (Fig. 2B); yet, FR3T3 did not block 
Table $2 I_{50}, C C_{50}$ and $\mathrm{SI}$ values of fractions and subfractions of $A$. heterophyllus leaves dichloromethane extracts

\begin{tabular}{|c|c|c|c|c|}
\hline Sample & & $\mathrm{IC}_{50}(\mu \mathrm{g} / \mathrm{mL})$ & $\mathrm{CC}_{50}(\mu \mathrm{g} / \mathrm{mL})$ & Selectivity Index \\
\hline \multirow[t]{4}{*}{ Fraction } & FR1 & $>100$ & $>1000$ & $>10$ \\
\hline & FR2 & $48.27 \pm 8.82$ & $>1000(1008.27 \pm 28.23)$ & $>20.72$ \\
\hline & FR3 & $3.79 \pm 2.35$ & $>100(193.77 \pm 9.40)$ & $>26.39$ \\
\hline & FR4 & $4.60 \pm 1.46$ & $>100(191.28 \pm 0.02)$ & $>21.76$ \\
\hline \multirow[t]{7}{*}{ Subfraction } & FR3T1 & $6.15 \pm 0.60$ & $>50(94.28 \pm 8.44)$ & $>8.13$ \\
\hline & FR3T2 & $<3.12$ & $>25(31.90 \pm 5.34)$ & $>8.01$ \\
\hline & FR3T3 & $4.69 \pm 0.95$ & $>100(130.14 \pm 27.92)$ & $>21.32$ \\
\hline & FR3T4 & $42.03 \pm 2.92$ & $>200(251.21 \pm 1.75)$ & $>4.76$ \\
\hline & FR3T5 & $6.84 \pm 1.15$ & $>25(38.76 \pm 0.07)$ & $>3.65$ \\
\hline & FR3T6 & $30.42 \pm 1.23$ & $>400(417.38 \pm 77.23)$ & $>13.15$ \\
\hline & FR3T7 & $2.39 \pm 0.34$ & $>12.5(16.16 \pm 9.75)$ & $>5.23$ \\
\hline
\end{tabular}

The experiment was performed in triplicate

HCV adsorption to the surface of Huh7it-1 cells (Fig. 2C). These results suggested that FR3T3 exerts anti$\mathrm{HCV}$ activity through both a direct virucidal effect and stimulating a host-related factor that influences viral entry; however, this antiviral impact at viral entry stage is relatively minor.

Next, we assessed the effect of FR3T3 at the post-viral entry stage. The FR3T3-containing medium was added to the cell culture after HCV infection, and the infected cells were incubated for $46 \mathrm{~h}$. The infected cells were analyzed for the levels of NS3 protein expression and HCV RNA replication in the cells. The immunoblotting results showed FR3T3 decreased the expression of NS3 protein compared with the untreated control (Fig. 3). Similarly, we observed inhibition of HCV RNA replication in the FR3T3-treated cells. A $20 \mu \mathrm{g} / \mathrm{mL}$ dose of FR3T3 reduced HCV RNA levels in treated cells by 35.5\% compared to the untreated control (Fig. 4). These results suggested that FR3T3 suppresses HCV replication after HCV entry.

\section{Chromatogram profiles of the DCM extract and fractions by TLC and LCMS}

To elucidate the derivates that were responsible for antiHCV activity in the FR3T3 sub-fraction, we conducted TLC analysis. Dark spots were observed under UV at $254 \mathrm{~nm}$ (Fig. 5A) and red spots were observed under UV at $365 \mathrm{~nm}$ (Fig. 5B and C). A green and purple spot was found after the resulting profile was sprayed with $10 \%$ sulfuric acid (Fig. 5D) which indicated that FR3T3 contains terpenoids and chlorophyll as major compounds.

Spectrum matching was performed from several peaks in FR3T3 to find out more about what compounds in these spectra were likely to be. A spectra peak with retention time of $32.17,32.88,34.87,35.59$, and $46.17 \mathrm{~min}$ were compatible with the spectra profile of chlorophyll compounds (Fig. 6A-E). Meanwhile, a spectra peak with a 49.17 retention time was unidentified yet (Fig. 6B). Based on TLC profile, the peak was possible to be terpenoids compound (Fig. 5D).

According to LCMS spectra, the Total Ion Chromatogram (TIC) was detected six peaks. The peak with retention time $0.90 ; 1.00 ; 1.26 ; 3.72 ; 6.29$ and 7.96 have $\mathrm{m} / \mathrm{z}$ 113.0690; m/z 317.1165; m/z 137.0215; m/z 113.1082; $\mathrm{m} / \mathrm{z} 451.3630$ and $\mathrm{m} / \mathrm{z} 677.4636[\mathrm{M}+\mathrm{H}]+$, respectively (Fig. 7).

\section{Combining the $A$. heterophyllus dichloromethane extract with current HCV treatments}

Next, we compared the $\mathrm{IC}_{50}$ of the DCM extract (NaDCM) of $A$. heterophyllus leaves with currently available $\mathrm{HCV}$ treatments. The $\mathrm{IC}_{50}$ value of $\mathrm{NaDCM}$ extract of A. heterophyllus was $1.43 \mu \mathrm{g} / \mathrm{mL}$ while Telaprevir, Simeprevir, Ribavirin and Cyclosporin had $\mathrm{IC}_{50}$ value of $9.01 \mathrm{nM}, 13.09 \mathrm{nM}, 10.04 \mu \mathrm{g} / \mathrm{mL}$, and $0.58 \mu \mathrm{g} / \mathrm{mL}$ respectively (Table 4).

We then examined the efficacy of $\mathrm{NaDCM}$ as a combination treatment. A 40 and $20 \mu \mathrm{g} / \mathrm{mL}$ Ribavirin

Table 3 Time-of-addition experiment of FR3T3

\begin{tabular}{lllll}
\hline No & Sample & Entry inhibition (\%) & Post-entry inhibition (\%) & Entry and post-entry inhibition (\%) \\
\hline 1 & FR3T3 $(10 \mu \mathrm{g} / \mathrm{mL})$ & $33.86 \pm 2.19$ & $64.04 \pm 3.06$ & $83.07 \pm 4.00$ \\
2 & FR3T3 $(20 \mu \mathrm{g} / \mathrm{mL})$ & $61.68 \pm 0.10$ & $83.86 \pm 2.58$ & $93.44 \pm 5.29$ \\
\hline
\end{tabular}

The experiment was performed in triplicate 
A

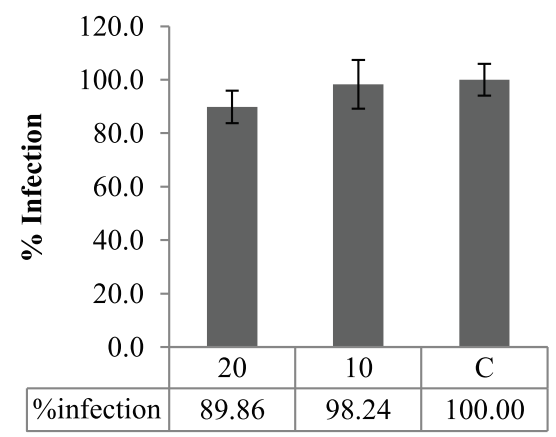

Concentration $\mu \mathrm{g} / \mathrm{mL}$
B

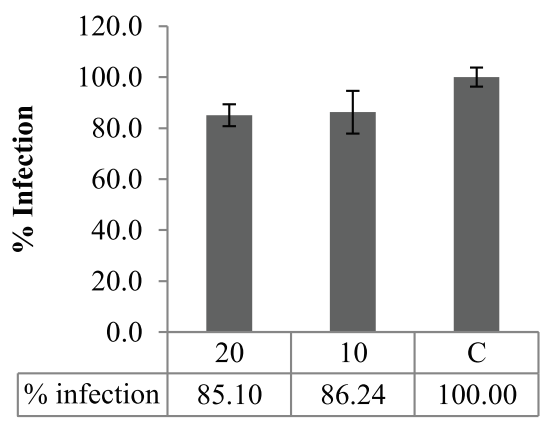

Concentration $\mu \mathrm{g} / \mathrm{mL}$

$\mathrm{C}$

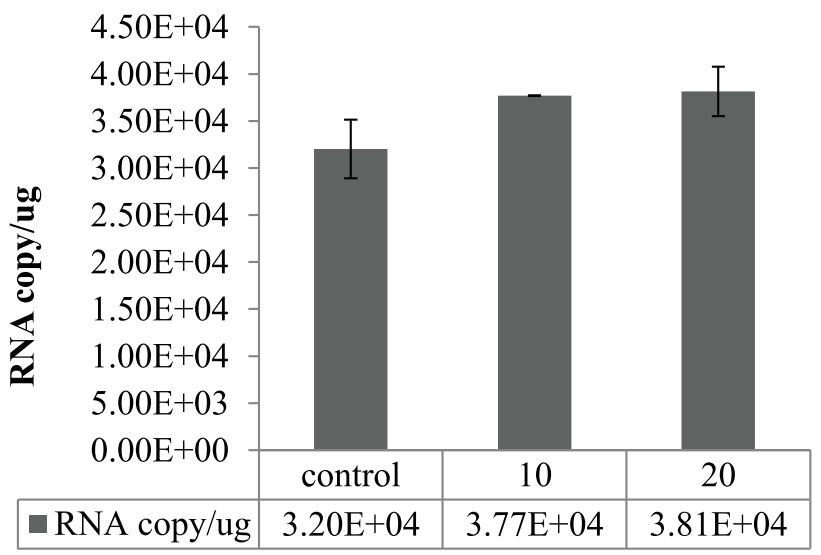

Fig. 2 The results of the mode of action assays from the entry stage. A The percentage of HCV infection in the virucidal activity assay of the FR3T3 sub-fraction, $\mathbf{B}$ the percentage of HCV infection in the host cell expression activity assay, $\mathbf{C}$ Number of copies of RNA from the VHC absorption test on FR3T3 sub-fraction treated Huh7it-1 cells

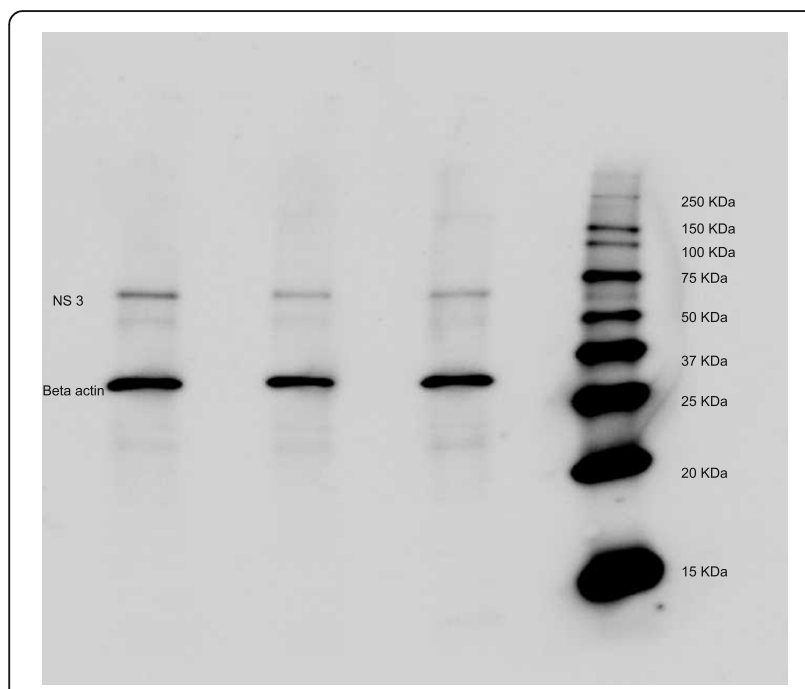

Fig. 3 The expression of HCV NS3 proteins after the treatment of cells post-viral entry treatment combined with $\mathrm{NaDCM}$ at all doses examined $(0.7-12.0 \mu \mathrm{g} / \mathrm{mL})$ produced a $100 \%$ inhibition of $\mathrm{HCV}$ growth. Ribavirin and NaDCM resulted in $>75 \%$ inhibition at all combined concentrations (Fig. 8A).

$\mathrm{NaDCM}$ and cyclosporin A inhibited 100\% of viral growth when Cyclosporin was administered in 2.4, 1.2, and $0.6 \mu \mathrm{g} /$ $\mathrm{mL}$ doses and $\mathrm{NaDCM}$ in 12.0, 6.0, and $3.0 \mu \mathrm{g} / \mathrm{mL}$ doses. An inhibition of $>70 \%$ of $\mathrm{HCV}$ growth was observed when administering $\geq 0.1 \mu \mathrm{g} / \mathrm{mL}$ dose of Cyclosporin, and $\geq 3 \mu \mathrm{g} / \mathrm{mL}$ of NaDCM (Fig. 8B). When administering $\geq 20 \mu \mathrm{M}$ Simeprevir, all concentrations of $\mathrm{NaDCM}(0.70-12.0 \mu \mathrm{g} / \mathrm{mL})$ inhibited $100 \%$ of $\mathrm{HCV}$ growth. The lowest concentrations of $\mathrm{NaDCM}(0.7 \mu \mathrm{g} / \mathrm{mL})$ and $10 \mu \mathrm{M}$ of Simeprevir inhibited $50 \%$ of HCV growth (Fig. 8C). Telaprevir inhibited $100 \%$ of $\mathrm{HCV}$ growth when $\geq 6 \mu \mathrm{g} / \mathrm{mL} \mathrm{NaDCM}$ was administered; however, $1.5 \mu \mathrm{g} / \mathrm{mL}$ of $\mathrm{NaDCM}$ lowered the inhibition of all of the telaprevir concentrations tested (Fig. 8D). 


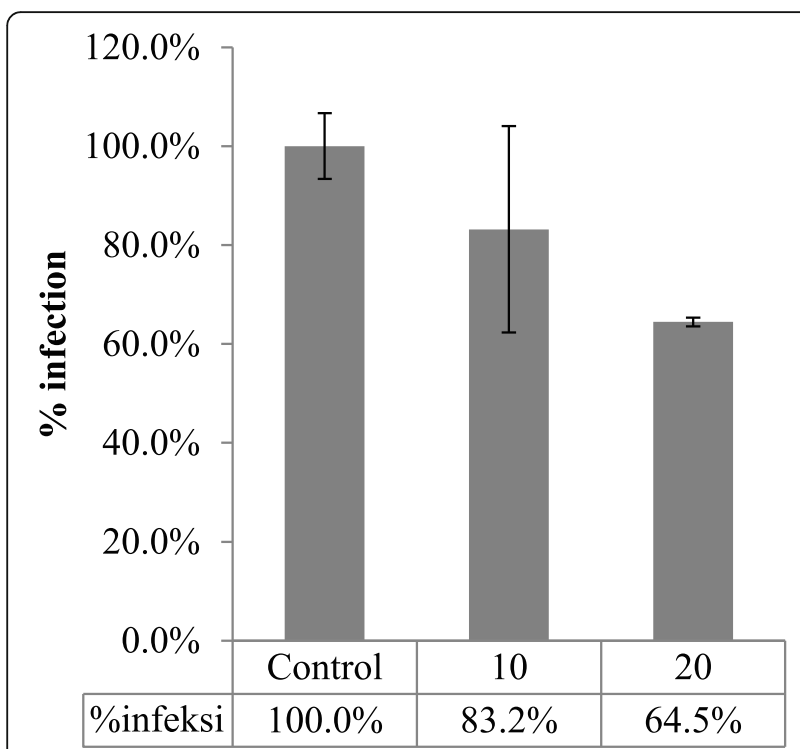

Fig. 4 The percentage of infection from HCV RNA replication after the administration of FR3T3 at a concentration of 10 and $20 \mu \mathrm{g} / \mathrm{mL}$
Next, we analyzed the dose-response curves from $\mathrm{NaDCM}$ at a concentration of $1.5 \mu \mathrm{g} / \mathrm{mL}$ combined with Ribavirin at 40.0, 20.0, 10.0, 5.0, and $2.5 \mu \mathrm{g} / \mathrm{mL}$ using Compusyn software. The combination index (CI) was < 1 , indicating that the two drugs work synergistically (Fig. 9A).

Compusyn analysis also indicated that $0.1,0.3,0.6,1.2$, and $2.4 \mu \mathrm{g} / \mathrm{mL}$ doses of Cyclosporin combined with $1.5 \mu \mathrm{g} / \mathrm{mL} \mathrm{NaDCM}$ produced CI values of $4.54,2.37$, $0.45,0.35$, and 0.15 respectively. These results suggested that three concentrations produce a synergistic effect while the other two concentrations produce an antagonistic effect. Therefore, a $1.5 \mu \mathrm{g} / \mathrm{mL}$ NaDCM dose should be combined with a minimum dose of $0.6 \mu \mathrm{g} / \mathrm{mL}$ of Cyclosporin for combination therapy (Fig. 9B). All combination doses of Simaprevir except for $10 \mathrm{mM}$ combined with a $1.5 \mu \mathrm{g} / \mathrm{mL}$ dose of $\mathrm{NaDCM}$ produced a synergistic effect (CI score $<1$; Fig. 9C). All doses of Telaprevir examined combined with a $1.5 \mu \mathrm{g} / \mathrm{mL}$ dose of $\mathrm{NaDCM}$ produced $\mathrm{CI}$ values that were $>1$ indicating an-

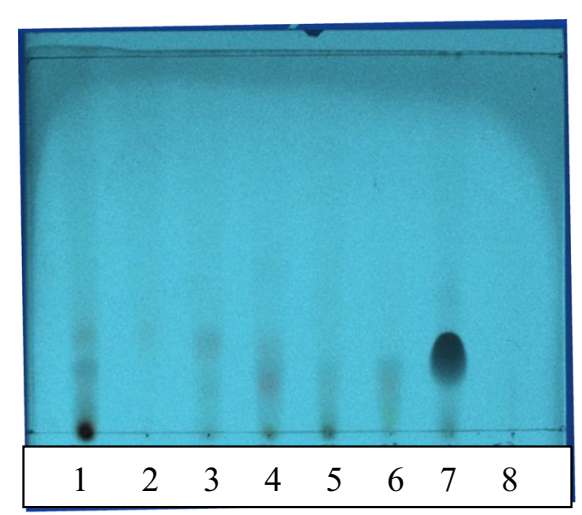

$254 \mathrm{~nm}$

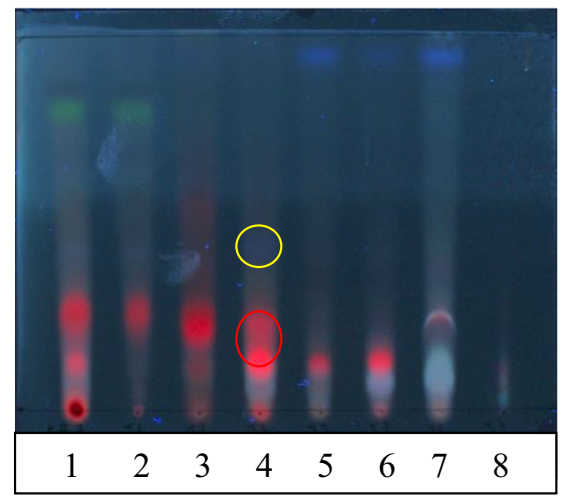

$\mathrm{H}_{2} \mathrm{SO}_{4} 10 \%(365 \mathrm{~nm})$

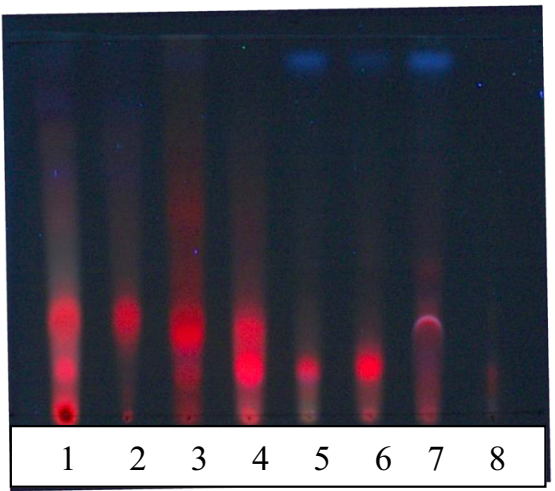

$365 \mathrm{~nm}$

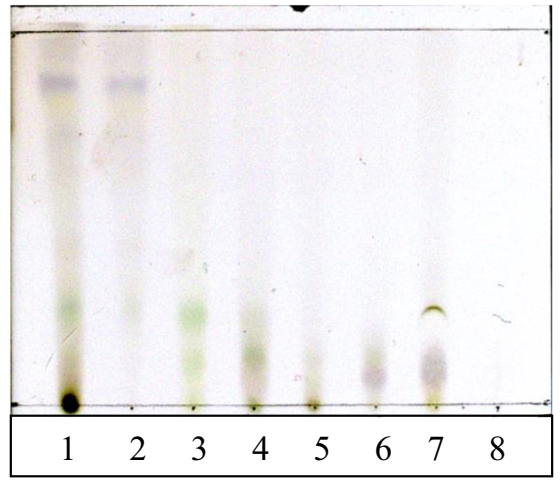

White

Fig. 5 The TLC pattern of sub-fraction 1-7 of FR3T. RP-18 TLC was used as stationary phase and methanol:water (95:5, v/v) as a mobile phase. (1) A. heterophyllus dichloromethane extract, (2) FR3T1, (3) FR3T2, (4) FR3T3, (5) FR3T4 (6) FR3T5, (7) FR3T6, (8) FR3T7 sub-fraction. Detection under $\mathbf{A}$ UV $254 \mathrm{~nm}$, B UV $365 \mathrm{~nm}$, C sprayed with 10\% sulfuric acid and heated at $105^{\circ} \mathrm{C}$ for 5 min then observed under UV $365 \mathrm{~nm}$ D observed under white lamp 

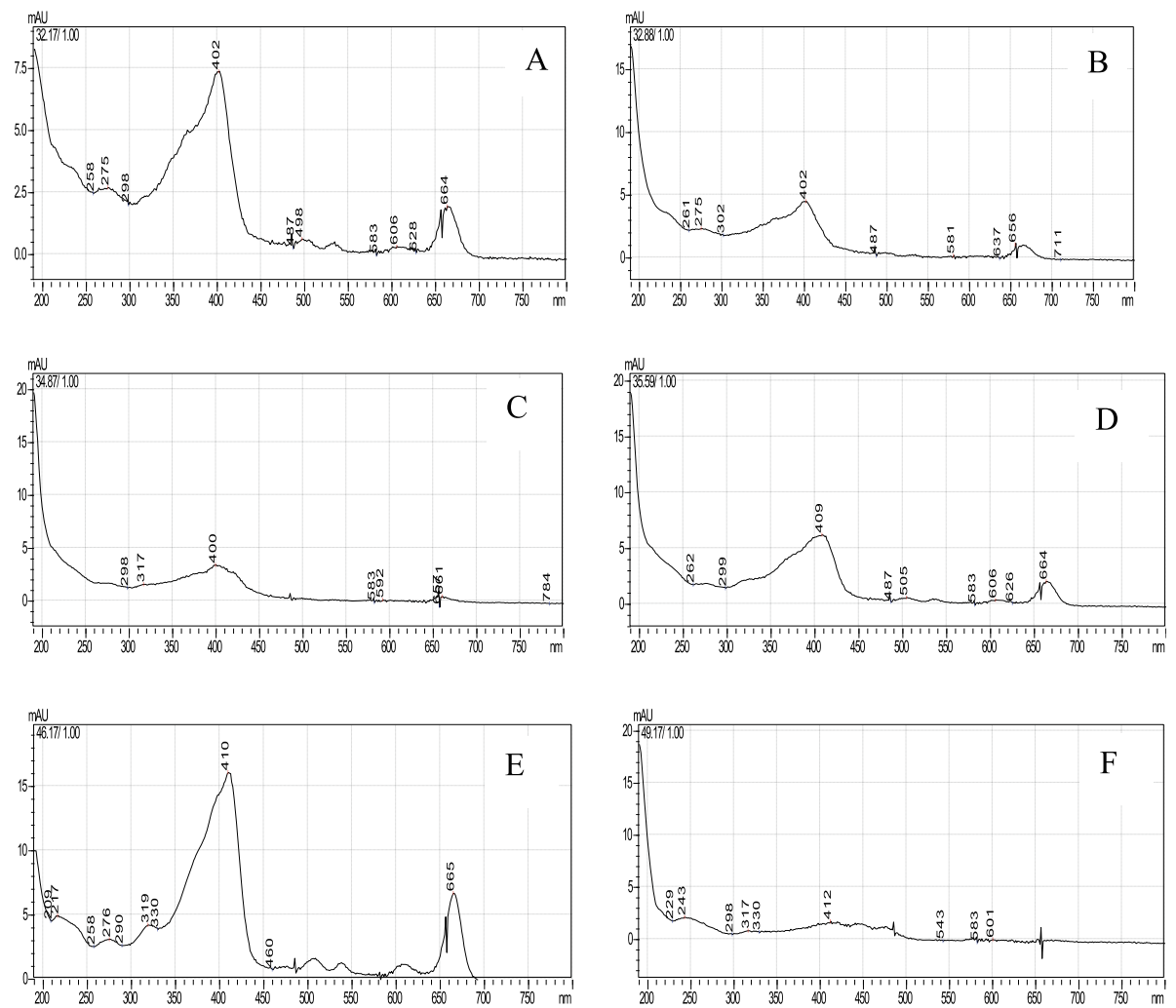

Fig. 6 The UV Spectra of FR3T3 sub-fraction peaks using HPLC. Zorbax Eclipse XDB-C18 column, mobile phase acetonitrile - water (9:1 v/v): flowrate $1 \mathrm{~mL} / \mathrm{min}$, wavelength $254 \mathrm{~nm}$, A Peak with a retention time (Rt) 32.17, B Peak with a Rt 32.88, C Peak with a Rt 34.87, D Peak with Rt 35.59, E Peak with Rt 46.17, F Peak with Rt 49.17

tagonism between these two treatments (Fig. 9D). The $\mathrm{IC}_{50}$ value of the combination of $\mathrm{NaDCM}$ extract (with various concentration of antiHCV drug was showed at Table 5.

\section{Discussion}

Many medicinal plants have been reported as promising potential anti-HCV agents, such as Magnolia officinalis,
Maytrenus ilicifolia, Silybum marianum, and Camellia sinensis [26, 29-31]. Extracts of these plants have been further refined into compounds that have been able to inhibit $\mathrm{HCV}$ at various points in its lifecycle. Oleanolic acid and ursolic acid were anti-HCV substances isolated from Ligustrum lucidum that could inhibit the HCV NS5B protein [32]. Chalepin and pseudane IX isolated

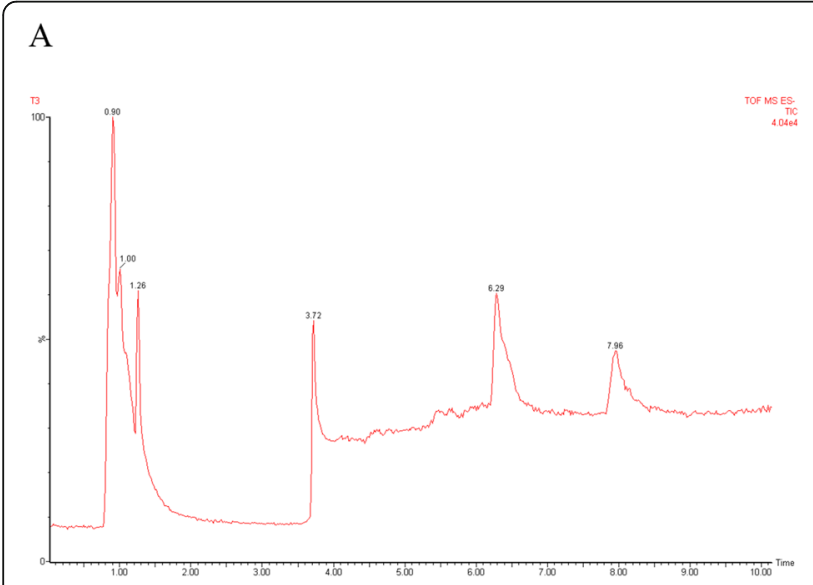

B

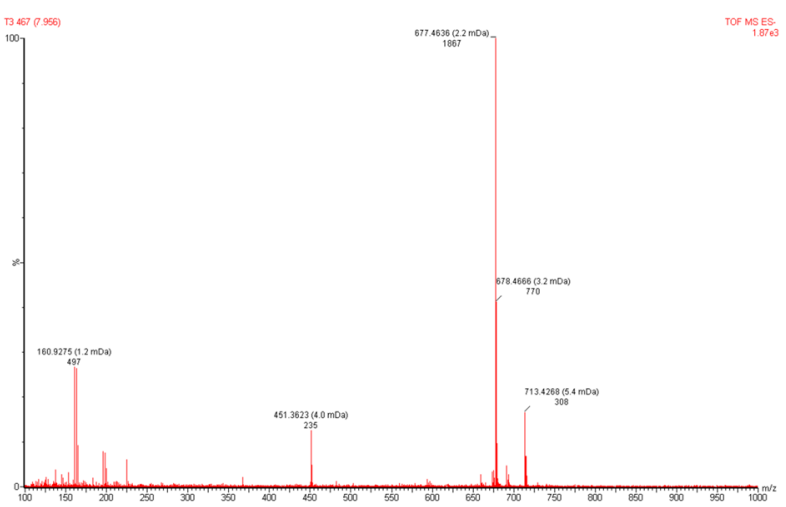

Fig. 7 Total ion chromatogram of FR3T3 subfraction (A), Mass Spectra of peak with Rt 7.96 min has m/z $677.4636[M+H]+($ B) 
Table $4 I_{50}$ of $A$. heterophyllus leaves Dichloromethane Extract, Telaprevir, Simaprevir, Ribavirin and Cyclosporin

\begin{tabular}{ll}
\hline Sample & $\mathbf{I C}_{\mathbf{5 0}}$ \\
\hline DCM extract & $1.43 \pm 0.05 \mu \mathrm{g} / \mathrm{mL}$ \\
Telaprevir & $9.01 \pm 0.20 \mathrm{nM}$ \\
Simeprevir & $13.09 \pm 1.24 \mathrm{nM}$ \\
Ribavirin & $10.04 \pm 0.06 \mu \mathrm{g} / \mathrm{mL}$ \\
Cyvlosporin A & $0.58 \pm 0.07 \mu \mathrm{g} / \mathrm{mL}$ \\
\hline The experiment was performed in triplicate &
\end{tabular}

from Ruta angustifolia as well as $\alpha$-mangostin and $\gamma$ mangostin isolated from Gracinia mangostana were all able to inhibit HCV RNA replication [22, 33]. Saiskoponin b2 isolated from Bupleurum koil inhibited viral entry [34].

In a previous study on A. heterophyllus leaves as anti$\mathrm{HCV}$, it was reported that ethanol, methanol, and dichloromethane extracts actively inhibited $\mathrm{HCV}$ with $\mathrm{IC}_{50}$ values of $12.9 \pm 2.6 \mathrm{~g} / \mathrm{mL}, 6.8 \pm 0.8 \mathrm{~g} / \mathrm{mL}$, and $1.5 \pm 0.6 \mathrm{~g} /$ $\mathrm{mL}$ respectively (Hafid et al., 2017). In this study, the dichloromethane extract was further separated to find the active sub-fraction that played a role in providing anti$\mathrm{HCV}$ activity using bioassay guided isolation. This was the first study to explore the presence of a synergistic effect between a dichloromethane extract of $A$. heterophyllus with several HCV drugs such as Simaprevir, Ribavirin, and Cyclosporin A.

The in vitro assay we performed using the JFH1a strain of HCV and Huh7it-1 cells demonstrated the dichloromethane extract of $A$. heterophyllus sub-fraction FR3T3 possesses anti-HCV properties. This anti-HCV activity occurred mainly through the post-entry stage by reducing NS3 protein expression and RNA replication. Nevertheless, FR3T3 had some anti-HCV activity in the $\mathrm{HCV}$ entry stage, demonstrated by the virucidal and cell pretreatment effects we observed; however, it was not as pronounced. FR3T3 was less effective at inhibiting HCV than the dichloromethane extract of A. heterophyllus. The dichloromethane of $A$. heterophyllus had an $\mathrm{IC}_{50}$ value of $1.43 \mu \mathrm{g} / \mathrm{mL}$ whereas the $\mathrm{IC}_{50}$ of the FR3T3 subfraction was $4.69 \pm 0.95 \mu \mathrm{g} / \mathrm{mL}$ (Table 2). These results suggest the dichloromethane of $A$. heterophyllus is more effective than the sub-fraction we isolated.

Through using Thin-layer Chromatography, we found that FR3T3 contained terpenoid and chlorophyll-related compounds. Some terpenoid compounds have reported as anti-HCV agents such as terpenoids isolated from Flueggea virosa [35], triterpenoid saponins from Platycodon grandiflorum [36] and diterpen lacton andrographolide from Andrographis paniculata [27]. Chlorophyll breakdown compounds from Morinda citrifolia, pheophorbide-a and pyropheophorbide-a, have also been identified as anti-HCV substances that inhibit $\mathrm{HCV}$ entry and replication [37].

Combination therapy using several drugs that each target different molecular pathways is considered a key strategy to achieve therapeutic success with lower doses. Combining the DCM extract of A.heterophyllus concentration $1.5 \mu \mathrm{g} / \mathrm{mL}$ with currently available $\mathrm{HCV}$ treatments (Simaprevir, Ribavirin, Cyclosporin A, and Telaprevir) resulted in synergistic effects on Simaprevir, Ribavirin, and Cyclosporin A with $\mathrm{CI}$ value $<1$. While there is antagonist effect if the active extract $(1.5 \mu \mathrm{g} / \mathrm{mL})$ was used with telaprevir with $\mathrm{CI}$ value $>1$. Simeprevir is

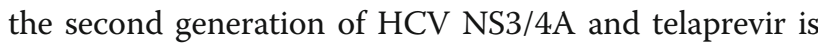
the first generation as $\mathrm{HCV}$ NS3/4A protease. Whereas Ribavirin and Cyclosprine act by interfere the host factor [38]. The synergistic effects of these combinations may be useful for patients infected by drug-resistant $\mathrm{HCV}$ strains.
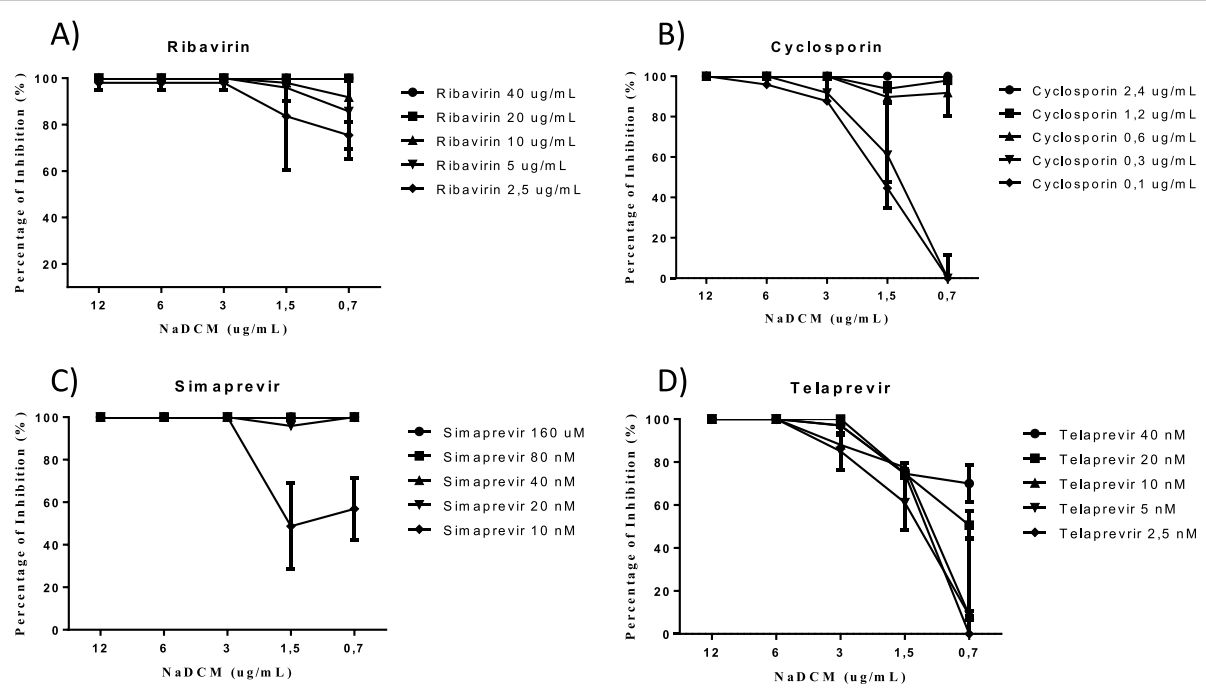

Fig. 8 Dose dependence inhibition of A Ribavirin, B Cyclosporin A, C Simaprevir, and D Telaprevir against HCV JFH1 

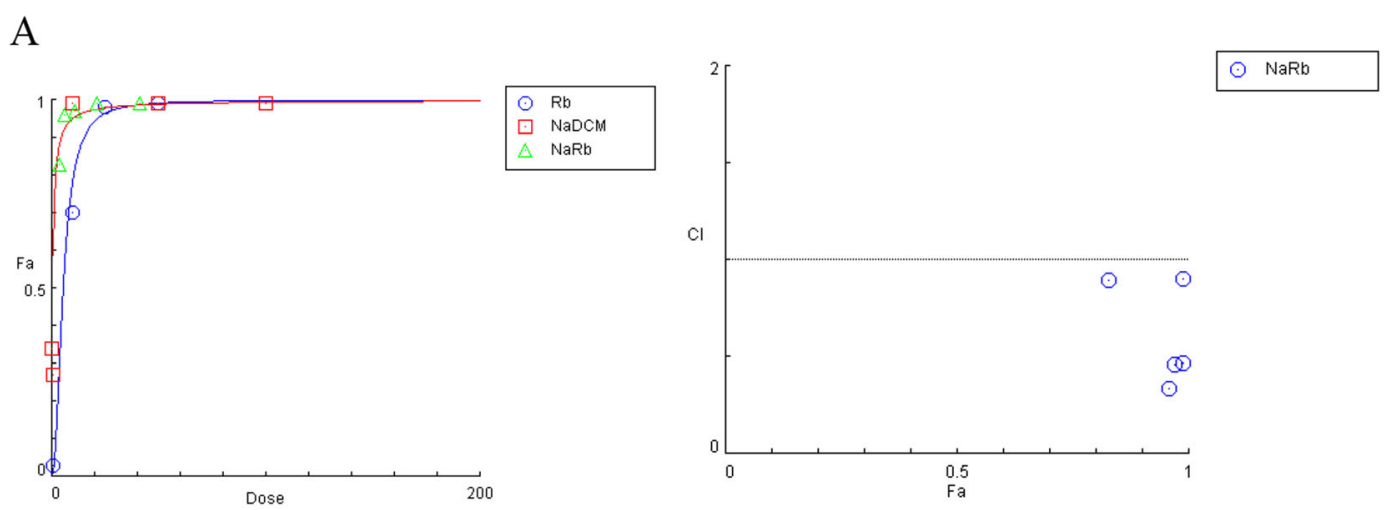

B
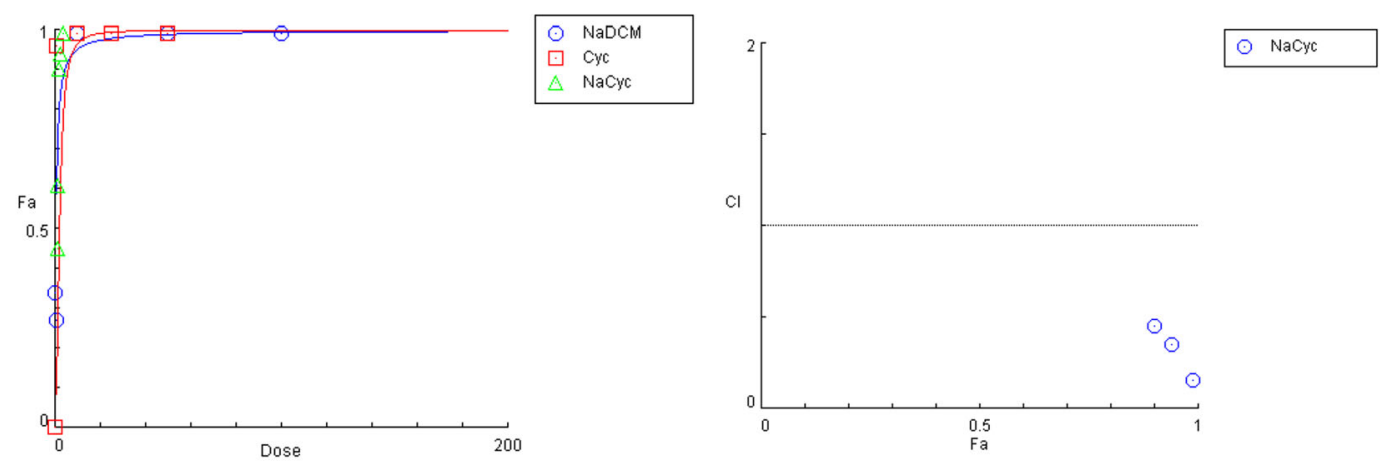

C
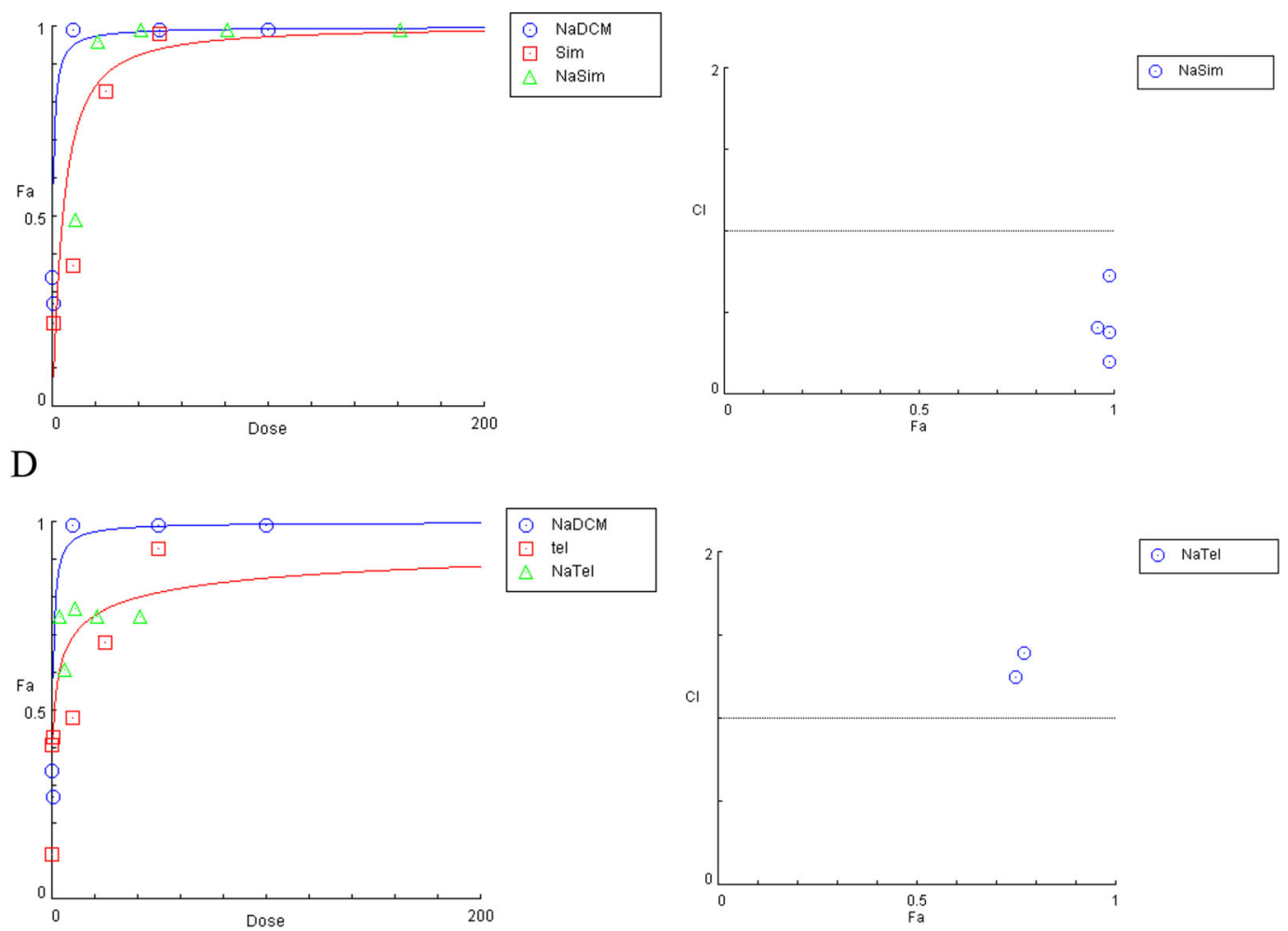

Fig. 9 The effect of a $1.5 \mu \mathrm{g} / \mathrm{mL}$ NaDCM dose combined common HCV treatments: A Ribavirin, B Cyclosporin A, C Simaprevir, and D Telaprevir 
Table $5 \mathrm{IC} 50$ of combination treatment of $\mathrm{NaDCM}(1.5 \mu \mathrm{g} / \mathrm{mL})$ with various concentration of antiHCV drug

\begin{tabular}{|c|c|c|c|c|c|}
\hline \multicolumn{6}{|c|}{$\mathrm{NaDCM}(1.5 \mu \mathrm{g} / \mathrm{mL})$} \\
\hline \multicolumn{3}{|l|}{ Ribavirin } & \multicolumn{3}{|l|}{ Cyclosporin } \\
\hline Conc (ug/mL) & IC50 & combination treatment & Conc (ug/mL) & IC50 & combination treatment \\
\hline 40.00 & $<0,1$ & Syn & 2.40 & $<0,03$ & Syn \\
\hline 20.00 & $<0,1$ & Syn & 1.20 & $0,03 \pm 0,03$ & Syn \\
\hline 10.00 & 0.32 & Syn & 0.60 & $0,19 \pm 0,12$ & Syn \\
\hline 5.00 & 0.47 & Syn & 0.30 & $1,20 \pm 0,60$ & Ant \\
\hline 2.50 & $0,4 \pm 0,3$ & Syn & 0.10 & $1,63 \pm 0,17$ & Ant \\
\hline \multicolumn{6}{|c|}{$\mathrm{NaDCM}(1.5 \mu \mathrm{g} / \mathrm{mL})$} \\
\hline Simaprevir & & & Telaprevir & & \\
\hline Conc (nM) & IC50 & combination treatment & Conc (nM) & IC50 & combination treatment \\
\hline 160.00 & $<0,7$ & Syn & 40.00 & $0,21 \pm 0,15$ & Ant \\
\hline 80.00 & $<0,7$ & Syn & 20.00 & $0,75 \pm 0,06$ & Ant \\
\hline 40.00 & $<0,7$ & Syn & 10.00 & $0,9 \pm 0,1$ & Ant \\
\hline 20.00 & $<0,7$ & Syn & 5.00 & $1,42 \pm 0,07$ & Ant \\
\hline 10.00 & $0,83 \pm 0,33$ & Ant & 2.50 & $1,22 \pm 0,09$ & Ant \\
\hline
\end{tabular}

Syn Synergism effect, Ant Antagonist effect

Some report have been published about combining natural compound together with several antiviral drugs including as combination treatment for $\mathrm{HCV}$. The combination of several antiviral drugs often show a greater inhibition activity and reduction in HCV RNA level than if it use in single treatment [39]. The curcumin have reported enhances inhibitory effects of boceprevir which known as NS3 protease inhibitor, Cyclosporin A, and Peg-IFN- $\alpha$ [40]. A polyphenol compound, Delphenidin, have improved the effectiveness of both boceprevir and IFN- $\alpha$ [41]. Moreover, the extracts of Phyllanthus amarus leaves used in combination with IFN- $\alpha$ exhibit synergistic effect against HCV in Rep 2a cells [42].

\section{Conclusion}

An extract produced from A. heterophyllus and its subfraction, FR3T3, displayed potential anti-HCV activities in this study. Therefore, they are promising drug, complementary or alternative medicine candidates for $\mathrm{HCV}$ infections. FR3T3 mainly inhibited the post-entry stage but produced a slight anti-HCV effect at the entry stage. A combined treatment of the dichloromethane extract of A. heteropyllus with Ribavirin, Cyclosporin, and Simaprevir produced synergistic effects.

\section{Abbreviations}

BSA: Bovine serum albumin; BCA: Bichincronic acid; $C_{50}$ : Cytotoxic concentration 50\%; DAAs: Direct acting anti-virals; DMEM: Dulbeco's Modiffied Eagle Medium; DMSO: Dimethyl sulfoxide; FBS: Fetal Bovine Serum; HCV: Hepatitis C virus; IC 50 : Inhibition concentration 50\%; MOI: Multiple of infection; NEAA: Non-essential amino acids; NMR: Nuclear magnetic resonance; PBS: Phosphate Buffer aline; SVR: Sustain virology respond UV: Ultra violet; VLC: Vacum liquid chromatography

\section{Acknowledgements}

We would like to thank to UNAIR researcher grant 2020 for funding the research, JICA/JST SATREPS 2010-2014 Project (Identification of antihepatitis $\mathrm{C}$ (HCV) subtances) for supporting the equipment and reagents, and JSPS Program 2018-2021 (Identification And Development Of New Antiviral Lead Compounds Against Hepatitis B From Indonesian Medicinal Plants) for transfer knowledge and sustainable research. Special thanks to Dr. Takaji Wakita to provide JFH1 and Dr. Yohko Shimizu to provide Huh7it-1.

\section{Authors' contributions}

Conceived and designed the experiment: AAP,CAU, TSW, and AFH. Analyzed the data: AAP, CAU, TSW, LT, and AFH. Contributed reagents/materials/ analysis tools: MA, AW, and $\mathrm{HH}$. Wrote the paper: AAP, CAU, TSW, and AFH. All authors read and approved the final manuscript.

\section{Funding}

This research was granted by UNAIR researcher grant 2020, JICA/JST SATREPS 2010-2015. JSPS Program 2018-2021.

\section{Availability of data and materials}

The all data used to support the findings of this study are available from the corresponding or the first authors upon request.

\section{Declarations}

Ethics approval and consent of participate Not applicable.

\section{Consent of publication}

Not applicable.

\section{Competing interests}

The authors declare that they have no conflict of interest.

\section{Author details}

${ }^{1}$ Institute of Tropical Disease, Universitas Airlangga, Surabaya 60115, Indonesia. ${ }^{2}$ Department of Public Health, Kobe University Graduate School of Health Sciences, 7-10-2, Tomogaoka, Suma-ku, Kobe 654-0142, Japan. ${ }^{3}$ Department of Pharmaceutical Sciences, Faculty of Pharmacy, Universitas Airlangga, Surabaya 60115, Indonesia. ${ }^{4}$ Department of Health, Study Program Traditional Medicine, Vocational Faculty, Universitas Airlangga, Surabaya, 
Indonesia. ${ }^{5}$ Faculty of Clinical Nutrition and Dietetics, Konan Women's University, 6-2-23, Morikita-machi, Higashida-ku, Kobe 658-0001, Japan.

\section{Received: 7 March 2021 Accepted: 13 August 2021 Published online: 12 October 2021}

\section{References}

1. Moradpour D, Penin F. Hepatitis C virus proteins: from structure to function. Curr Top Microbiol Immunol. 2013;369:113-42. https://doi.org/10.1007/ 978-3-642-27340-7_5.

2. Jones DM, McLauchlan J. Hepatitis C virus: assembly and release of virus particles. J Biol Chem. 2010;285(30):22733-9. https://doi.org/10.1074/jbc.R11 0.133017 .

3. Gerold G, Pietschmann T. The HCV life cycle: in vitro tissue culture systems and therapeutic targets. Dig Dis. 2014;32(5):525-37. https://doi.org/10.1159/ 000360830.

4. Dustin LB, Bartolini B, Capobianchi MR, Pistello M. Hepatitis C virus: life cycle in cells, infection and host response, and analysis of molecular markers influencing the outcome of infection and response to therapy. Clin Microbiol Infect. 2016;22(10):826-32. https://doi.org/10.1016/j.cmi.2 016.08.025.

5. Update on Hepatitis C Epidemiology: Unaware and Untreated Infected Population Could Be the Key to Elimination. SN Compr Clin Med. 2020;18: 1-8. https://doi.org/10.1007/s42399-020-00588-3.

6. Mohamed AA, Elbedewy TA, El-Serafy M, El-Toukhy N, Ahmed W, Ali El Din Z. Hepatitis C virus: a global view. World J Hepatol. 2015;7(26):2676-80. https://doi.org/10.4254/wjh.v7.i26.2676.

7. Messina JP, Humphreys I, Flaxman A, Brown A, Cooke GS, Pybus OG, et al. Global distribution and prevalence of hepatitis $C$ virus genotypes. Hepatology. 2015;61(1):77-87. https://doi.org/10.1002/hep.27259.

8. Tamori A, Enomoto M, Kawada N. Recent advances in antiviral therapy for chronic hepatitis C. Mediat Inflamm. 2016;2016:6841628-11. https://doi. org/10.1155/2016/6841628.

9. Chen ZW, Li H, Ren H, Hu P. Global prevalence of pre-existing HCV variants resistant to direct-acting antiviral agents (DAAs): mining the GenBank HCV genome data. Sci Rep. 2016;6(1):20310. https://doi.org/10.1038/srep20310.

10. Pawlotsky JM. Hepatitis C virus: standard-of-care treatment. Adv Pharmacol. 2013;67:169-215. https://doi.org/10.1016/B978-0-12-405880-4.00005-6.

11. Nitta S, Asahina Y, Matsuda M, Yamada N, Sugiyama R, Masaki T, et al. Effects of resistance-associated NS5A mutations in hepatitis C virus on viral production and susceptibility to antiviral reagents. Sci Rep. 2016;6(1):34652. https://doi.org/10.1038/srep34652.

12. Wahyuni TS, Aoki C, Hotta H. Promising anti-virus hepatitis $\mathrm{C}$ compounds from natural resources. Nat Prod Commun. 2016;11(8):1193-200. https://doi. org/10.1177/1934578X1601100840.

13. Veeresham C. Natural products derived from plants as a source of drugs. $\rfloor$ Adv Pharm Technol Res. 2012;3(4):200-1. https://doi.org/10.4103/2231-404 0.104709 .

14. Jassim SA, Naji MA. Novel antiviral agents: a medicinal plant perspective. J Appl Microbiol. 2003;95(3):412-27. https://doi.org/10.1046/.j.1365-2672.2003. 02026.x.

15. Verheij EWM, Coronel RE. Plant resources of South-East Asia. Bogor: Prosea; 1992.

16. Jagtap UB, Bapat VA. Artocarpus: a review of its traditional uses, phytochemistry and pharmacology. J Ethnopharmacol. 2010;129(2):142-66. https://doi.org/10.1016/j.jep.2010.03.031

17. Jensen MM, Wright DN, Robison RA. Microbiology for the health sciences. London: Prentice Hall, International Inc:; 1977.

18. Likhitwitayawuid K, Chaiwiriya S, Sritularak B, Lipipun V. Antiherpetic flavones from the heartwood of Artocarpus gomezianus. Chem Biodivers. 2006;3(10):1138-43. https://doi.org/10.1002/cbdv.200690115.

19. Sasivimolphan $P$, Lipipun $V$, Likhitwitayawuid $K$, Takemoto M, Pramyothin $P$, Hattori $M$, et al. Inhibitory activity of oxyresveratrol on wild-type and drugresistant varicella-zoster virus replication in vitro. Antivir Res. 2009;84(1):95-7. https://doi.org/10.1016/j.antiviral.2009.07.010.

20. Wetprasit N, Threesangsri W, Klamklai N, Chulavatnatol M. Jackfruit lectin: properties of mitogenicity and the inhibition of herpesvirus infection. Jpn J Infect Dis. 2000;53(4):156-61.

21. Hafid AF, Utsubo CA, Permanasari AA, Adianti M, Tumewu L, Widyawaruyanti $A$, et al. Antiviral activity of the dichloromethane extracts from Artocarpus heterophyllus leaves against hepatitis C virus. Asian Pac J Trop Biomed. 2017;7(7):633-9.

22. Wahyuni TS, Widyawaruyanti A, Lusida MI, Fuad A, Soetjipto, Fuchino H, et al. Inhibition of hepatitis C virus replication by chalepin and pseudane IX isolated from Ruta angustifolia leaves. Fitoterapia. 2014;99:276-83. https:// doi.org/10.1016/j.fitote.2014.10.011

23. Aoki C, Hartati S, Santi MR, Lydwina T, Firdaus R, Hanafi M, et al. Isolation and identification of substances with anti-hepatitis $C$ virus activities from Kalanchoe pinnata. Int J Pharm Pharm Sci. 2014;6(2):211-5.

24. Aoki C, Hartati S, Santi MR, Lydwina L, Firdaus R, Hanafi M, et al. Isolation and identification of substances with anti-virus hepatitis $C$ activities from Kalanchoe Pinnata. Int J Pharm Pharm Sci. 2014;6(2):211-5.

25. Widyawaruyanti A, Tanjung M, Permanasari AA, Saputri R, Tumewu L, Adianti M, et al. Alkaloid and benzopyran compounds of Melicope latifolia fruit exhibit anti-hepatitis $C$ virus activities. BMC Complement Med Ther. 2021;21(1):27. https://doi.org/10.1186/s12906-021-03202-8.

26. Ciesek S, von Hahn T, Colpitts CC, Schang LM, Friesland M, Steinmann J, et al. The green tea polyphenol, epigallocatechin-3-gallate, inhibits hepatitis C virus entry. Hepatology. 2011;54(6):1947-55. https://doi.org/10.1002/ hep.24610.

27. Lee JC, Tseng CK, Young KC, Sun HY, Wang SW, Chen WC, et al. Andrographolide exerts anti-hepatitis $C$ virus activity by up-regulating haeme oxygenase-1 via the p38 MAPK/Nrf2 pathway in human hepatoma cells. Br J Pharmacol. 2014;171(1):237-52. https://doi.org/1 $0.1111 / \mathrm{bph} .12440$

28. Chou TC. Drug combination studies and their synergy quantification using the Chou-Talalay method. Cancer Res. 2010;70(2):440-6. https://doi.org/1 0.1158/0008-5472.CAN-09-1947.

29. Lan KH, Wang YW, Lee WP, Lan KL, Tseng SH, Hung LR, et al. Multiple effects of Honokiol on the life cycle of hepatitis C virus. Liver Int. 2012;32(6): 989-97. https://doi.org/10.1111/j.1478-3231.2011.02621.x.

30. Jardim AC, Igloi Z, Shimizu JF, Santos VA, Felippe LG, Mazzeu BF, et al. Natural compounds isolated from Brazilian plants are potent inhibitors of hepatitis C virus replication in vitro. Antivir Res. 2015;115:39-47. https://doi. org/10.1016/j.antiviral.2014.12.018.

31. Blaising J, Levy PL, Gondeau C, Phelip C, Varbanov M, Teissier E, et al. Silibinin inhibits hepatitis $C$ virus entry into hepatocytes by hindering clathrin-dependent trafficking. Cell Microbiol. 2013;15(11):1866-82. https:// doi.org/10.1111/cmi.12155.

32. Kong L, Li S, Liao Q, Zhang Y, Sun R, Zhu X, et al. Oleanolic acid and ursolic acid: novel hepatitis $C$ virus antivirals that inhibit NS5B activity. Antivir Res. 2013;98(1):44-53. https://doi.org/10.1016/j.antiviral.2013.02.003.

33. Choi M, Kim YM, Lee S, Chin YW, Lee C. Mangosteen xanthones suppress hepatitis C virus genome replication. Virus Genes. 2014;49(2):208-22. https:// doi.org/10.1007/s11262-014-1098-0.

34. Lin LT, Chung CY, Hsu WC, Chang SP, Hung TC, Shields J, et al. Saikosaponin b2 is a naturally occurring terpenoid that efficiently inhibits hepatitis C virus entry. J Hepatol. 2015;62(3):541-8. https://doi. org/10.1016/j.jhep.2014.10.040.

35. Chao CH, Cheng JC, Shen DY, Huang HC, Wu YC, Wu TS. Terpenoids from Flueggea virosa and their anti-hepatitis $C$ virus activity. Phytochemistry. 2016;128:60-70. https://doi.org/10.1016/j.phytochem.2016.04.003.

36. Kim JW, Park SJ, Lim JH, Yang JW, Shin JC, Lee SW, et al. Triterpenoid Saponins isolated from Platycodon grandiflorum inhibit hepatitis $C$ virus replication. Evid Based Complement Alternat Med. 2013;2013:560417-1. https://doi.org/10.1155/2013/560417.

37. Ratnoglik SL, Aoki C, Sudarmono P, Komoto M, Deng L, Shoji I, et al. Antiviral activity of extracts from Morinda citrifolia leaves and chlorophyll catabolites, pheophorbide a and pyropheophorbide a, against hepatitis C virus. Microbiol Immunol. 2014;58(3):188-94. https://doi.org/10.1111/13480421.12133.

38. Kish T, Aziz A, Sorio M. Hepatitis $C$ in a new era: a review of current therapies. Pharm Ther. 2017;42(5):316-29.

39. Lin K, Perni RB, Kwong AD, Lin C. VX-950, a novel hepatitis C virus (HCV) NS3-4A protease inhibitor, exhibits potent antiviral activities in HCv replicon cells. Antimicrob Agents Chemother. 2006;50(5):1813-22. https://doi.org/1 0.1128/AAC.50.5.1813-1822.2006.

40. Anggakusuma, Colpitts CC, Schang LM, Rachmawati H, Frentzen A, Pfaender $\mathrm{S}$, et al. Turmeric curcumin inhibits entry of all hepatitis $C$ virus genotypes into human liver cells. Gut. 2014;63(7):1137-49. https://doi.org/10.1136/ gutjhl-2012-304299. 
41. Calland N, Sahuc ME, Belouzard S, Pene V, Bonnafous P, Mesalam AA, et al. Polyphenols inhibit hepatitis $C$ virus entry by a new mechanism of action. J Virol. 2015;89(19):10053-63. https://doi.org/10.1128/JVI.01473-15.

42. Ravikumar YS, Ray U, Nandhitha M, Perween A, Raja Naika H, Khanna N,

et al. Inhibition of hepatitis $\mathrm{C}$ virus replication by herbal extract: Phyllanthus amarus as potent natural source. Virus Res. 2011;158(1-2):89-97. https://doi. org/10.1016/j.virusres.2011.03.014.

\section{Publisher's Note}

Springer Nature remains neutral with regard to jurisdictional claims in published maps and institutional affiliations.

Ready to submit your research? Choose BMC and benefit from:

- fast, convenient online submission

- thorough peer review by experienced researchers in your field

- rapid publication on acceptance

- support for research data, including large and complex data types

- gold Open Access which fosters wider collaboration and increased citations

- maximum visibility for your research: over $100 \mathrm{M}$ website views per year

At $\mathrm{BMC}$, research is always in progress.

Learn more biomedcentral.com/submissions 